\title{
Light-level geolocators reveal spatial variations in interactions between northern fulmars and fisheries
}

\author{
Benjamin Dupuis ${ }^{1,2, \#}$, Françoise Amélineau ${ }^{2, \#, *}$, Arnaud Tarroux ${ }^{3}$, Oskar Bjørnstad ${ }^{4}$, \\ Vegard Sandøy Bråthen ${ }^{5}$, Jóhannis Danielsen ${ }^{6}$, Sébastien Descamps ${ }^{2}$, Per Fauchald ${ }^{3}$, \\ Gunnar Thor Hallgrimsson ${ }^{7}$, Erpur Snær Hansen ${ }^{8}$, Morten Helberg ${ }^{9}$, Hálfdán Helgi \\ Helgason ${ }^{2,13}$, Jón Einar Jónsson ${ }^{10}$, Yann Kolbeinsson ${ }^{11}$, Erlend Lorentzen ${ }^{2}$, \\ Paul Thompson ${ }^{12}$, Thorkell Lindberg Thórarinsson ${ }^{11}$, Hallvard Strøm ${ }^{2}$
}

\author{
${ }^{1}$ Ecole Normale Supérieure de Lyon, Université Claude Bernard Lyon I, Université de Lyon, 69342 Lyon Cedex 07, France \\ ${ }^{2}$ Norwegian Polar Institute, Fram Centre, 9296 Tromsø, Norway \\ ${ }^{3}$ Norwegian Institute for Nature Research, Fram Centre, 9296 Tromsø, Norway \\ ${ }^{4}$ Grødheimvegen 18, 4280 Skudeneshavn, Norway \\ ${ }^{5}$ Norwegian Institute for Nature Research, PO Box 5685 Torgard, 7485 Trondheim, Norway \\ ${ }^{6}$ Faroe Marine Research Institute, Nóatún 1, 100 Tórshavn, Faroe Islands \\ ${ }^{7}$ Faculty of Life and Environmental Sciences, University of Iceland, Sturlugata 7, 102 Reykjavik, Iceland \\ ${ }^{8}$ South Iceland Nature Research Centre, Egisgata 2, 900 Vestmannaeyjar, Iceland \\ ${ }^{9}$ Østfold University College, PO Box 700, 1757 Halden, Norway \\ ${ }^{10}$ University of Iceland's Research Centre at Snæfellsnes, Hafnargata 3, 340 Stykkishólmur, Iceland \\ ${ }^{11}$ Northeast Iceland Nature Research Centre, Hafnarstétt 3, 640 Húsavík, Iceland \\ ${ }^{12}$ Lighthouse Field Station, School of Biological Sciences, University of Aberdeen, IV11 8YL, UK \\ ${ }^{13}$ Present address: East Iceland Nature Research Centre, Mýrargötu 10, 740 Neskaupstaður, Iceland
}

\begin{abstract}
Seabird-fishery interactions are a common phenomenon of conservation concern. Here, we highlight how light-level geolocators provide promising opportunities to study these interactions. By examining raw light data, it is possible to detect encounters with artificial lights at night, while conductivity data give insight on seabird behaviour during encounters. We used geolocator data from 336 northern fulmars Fulmarus glacialis tracked from 12 colonies in the North-East Atlantic and Barents Sea during the non-breeding season to (1) confirm that detections of artificial lights correspond to encounters with fishing vessels by comparing overlap between fishing effort and both the position of detections and the activity of birds during encounters, (2) assess spatial differences in the number of encounters among wintering areas and (3) test whether some individuals forage around fishing vessels more often than others. Most (88.1\%) of the tracks encountered artificial light at least once, with $9.5 \pm 0.4(\mathrm{SE})$ detections on average per 6 mo nonbreeding season. Encounters occurred more frequently where fishing effort was high, and birds from some colonies had higher probabilities of encountering lights at night. During encounters, fulmars spent more time foraging and less time resting, strongly suggesting that artificial lights reflect the activity of birds around fishing vessels. Inter-individual variability in the probability of encountering light was high (range: 0-68 encounters per 6 mo non-breeding season), meaning that some individuals were more often associated with fishing vessels than others, independently of their colony of origin. Our study highlights the potential of geolocators to study seabird-fishery interactions at a large scale and a low cost.
\end{abstract}

KEY WORDS: Seabird-fishery interactions · Global location sensor · GLS · Fulmarus glacialis · Activity budget $\cdot$ Discards $\cdot$ Management policy

\#These authors contributed equally to this work

*Corresponding author: francoise.amelineau@gmail.com

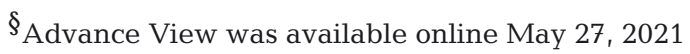

() The authors 2021. Open Access under Creative Commons by Attribution Licence. Use, distribution and reproduction are unrestricted. Authors and original publication must be credited. 


\section{INTRODUCTION}

Fishing activities affect the ecology of many marine species (Humphries \& Huettmann 2014, Diaz Pauli \& Sih 2017), including both target-fish populations (Ivanova et al. 2020) and their predators, such as seabirds (Cianchetti-Benedetti et al. 2018). Seabirdfishery interactions can affect seabirds through different degrees of reliance on fisheries in their foraging strategies (Bearhop et al. 2001), distribution (Bartumeus et al. 2010) and population dynamics (Oro et al. 2004). These interactions can take various forms but are often negative for seabirds. This applies notably to bycatch, where the incidental capture of non-targeted species (e.g. seabirds, marine mammals) can severely impact seabird populations in many ecosystems (Wagner \& Boersma 2011). Moreover, bycatch is often highly biased by sex and age (Gianuca et al. 2017), which can increase the impacts of bycatch on seabird populations (Barbraud et al. 2012, Gianuca et al. 2017). Seabird-fisheries interactions can also be indirect through competition for food resources, as the birds and fishers often exploit the same prey. This competition can lead to declines in seabird populations (Crawford et al. 1985, Wagner \& Boersma 2011, Barbraud et al. 2018, Grémillet et al. 2018) or hinder seabird foraging efficiency (Bertrand et al. 2012). However, fisheries can also have positive effects on seabirds, for instance when triggering an increase in prey abundance if competitors or predators are fished (Wagner \& Boersma 2011, Jurinovic et al. 2019), or by providing discards and offal (Le Bot et al. 2018).

Fishery discards (the proportion of catch that is not retained on board, such as fish below legal landing size, unmarketable species or species above quota restrictions) have been a major ecological issue since the intensification of fishing. In the North Atlantic, gradual regulations and technological improvements since the end of the 1980s (Kelleher 2005, Clark et al. 2020) have encouraged a more sustainable fishing industry, but some discarding still occurs (Watson 2017, Weimerskirch et al. 2020). This includes discarding of offal (organs and processing waste that are removed from the catch and thrown back into the sea) that represents an easily handled and highly calorific source of food for seabirds (Tasker 2000). Many studies have tried to quantify the consequences of seabirds feeding on fishery discards: by assessing spatial overlap between seabirds and fisheries (Cianchetti-Benedetti et al. 2018, Jurinovic et al. 2019, Clark et al. 2020); making direct observations onboard fishing vessels (Yeh et al. 2013); or using animal-borne cameras (Votier et al. 2013).
More recently, another technique has been used, based on the raw light data recorded by light-level geolocators (global location sensors, GLS) - small data devices recording light to determine twicedaily positions of birds during the non-breeding season (Krüger et al. 2017). Given that nocturnal fisheries typically use intense light sources on deck, evidence of close encounters with these artificial light sources is recorded by geolocators attached to those individuals coming close to fishing boats at night. These devices also record conductivity (indicating contact with water) that can be used to infer bird behaviour during encounters (hereafter referred to as activity).

The intensity of interactions between seabirds and fisheries varies among species and areas (Furness 2003, Krüger et al. 2017, Grémillet et al. 2019, Jurinovic et al. 2019). It is important to understand how such differences are affected by factors such as fishing intensity (Clark et al. 2020) or discarding regulations (Sturludottir 2018). Reduced discards, for example, may benefit some seabird species through a reduction of bycatch risk (Bicknell et al. 2013). In addition, discards might be nutritionally inferior to natural prey (Grémillet et al. 2008), so that stricter discarding regulations would force the birds to concentrate their foraging efforts on more valuable food sources. For generalist seabirds, reduced discards may have negative effects in the absence of alternative sources of food (Bicknell et al. 2013). Reduced availability of discards may lead to prey switching, with some species predating other seabirds, their chicks and eggs (Regehr \& Montevecchi 1997) or increasing kleptoparasitism (Martínez-Abraín et al. 2003), which can result in population-level impacts for affected species (Heubeck et al. 1999, Votier et al. 2008).

Among seabirds, procellariforms are often attracted to fisheries (Thompson 2006), and studies of these seabird-fishery interactions (Cianchetti-Benedetti et al. 2018, Weimerskirch et al. 2020) provide extensive evidence of discard consumption (Phillips et al. 1999, Sturludottir 2018). Previous studies using geolocators on procellariforms suggest that conductivity data provide reliable measures of activity during the nonbreeding season, with prolonged dry periods indicating flight, prolonged wet periods indicating resting on the sea surface, and rapidly alternating between wet and dry indicating foraging (Gutowsky et al. 2014, Krüger et al. 2017).

In this study, we aimed to identify and quantify encounters between fisheries and northern fulmars Fulmarus glacialis in relation to broad-scale differences in fishing intensities within the North-East 
Atlantic and Barents Sea. Our objectives were to (1) test the hypothesis that light detections correspond to encounters with fishing vessels in our study system, (2) assess whether birds change their activity when encountering artificial lights, (3) look at spatial variations in the probability and duration of encounters and (4) investigate the degree to which individuals might specialise in foraging near fishing vessels during the non-breeding season.

To achieve these aims, northern fulmars were equipped with GLS in different colonies across the North-East Atlantic and the Barents Sea. Previous studies have shown that several procellariform species, including northern fulmars, tend to overlap with fisheries (Camphuysen \& Garthe 1997, Copello \& Quintana 2009, Krüger et al. 2017) and are attracted by artificial lights (Rodríguez \& Rodríguez 2009, Troy et al. 2013). If artificial light detections at night correspond to encounters with fishing vessels, we predicted that there will be high overlap between the positions of the detections and fishing effort (Krüger et al. 2017). In addition, we predicted that, if they take advantage of discards and offal from fishing vessels, fulmars will spend more time foraging during encounters (Camphuysen \& Garthe 1997, Krüger et al. 2017). In contrast, if fulmars mostly follow boats that are not fishing, without feeding on discards, we predicted that they will spend more time flying (conductivity of 0 ) during the encounters. As fishing effort and discard ban policies vary between wintering areas (Kelleher 2005), we expected spatial variations in the number and duration of encounters (Bodey et al. 2014). For example, fulmars might stay longer in the vicinity of fishing vessels that are discarding larger quantities because of an increased prey abundance (Tasker 2000, Weimerskirch et al. 2000). Finally, from a conservation perspective, while conductivity data provide input on fulmar behaviour during encounters (e.g. they might be more vulnerable to bycatch if they are foraging than if they are only following vessels), it is also important to know whether some individuals, or individuals from specific colonies, encounter fishing vessels more often than others do, as increased encounters can influence population vulnerability to bycatch, and this information can be used to design conservation measures (Granadeiro et al. 2014, Patrick et al. 2015, Tyson et al. 2015).

\section{MATERIALS AND METHODS}

\subsection{Study species and logger deployment}

A total of 336 northern fulmars from 13 colonies (Fig. 1) were equipped with light-level geolocators (GLS) between 2007 and 2018. Colonies used in this study covered a large range of the overall fulmar distribution in the North-East Atlantic (Mallory et al. 2020). Icelandic colonies closer than $150 \mathrm{~km}$ to each other were grouped due to their proximity (Breidafjordur and Reykjanes, Langanes, Skjálfandi and Grimsey, Papey and Hólmanes). Birds were captured at their nest during one breeding season, banded and fitted with Migrate Technology (w65, c65, c65_super, f100, c250, c330), BAS (mk13, mk14, mk18, mk15, mk19, mk3, mk4, mk7) or Biotrack (mk4093, mk4083, mk3006, mk3005) loggers mounted on a plastic ring (see Table S1 in the Supplement at www.int-res.com/ articles/suppl/m676p159_supp.pdf). Instrumented individuals were recaptured 1-5 yr later to recover the GLS. Some individuals were equipped several times.
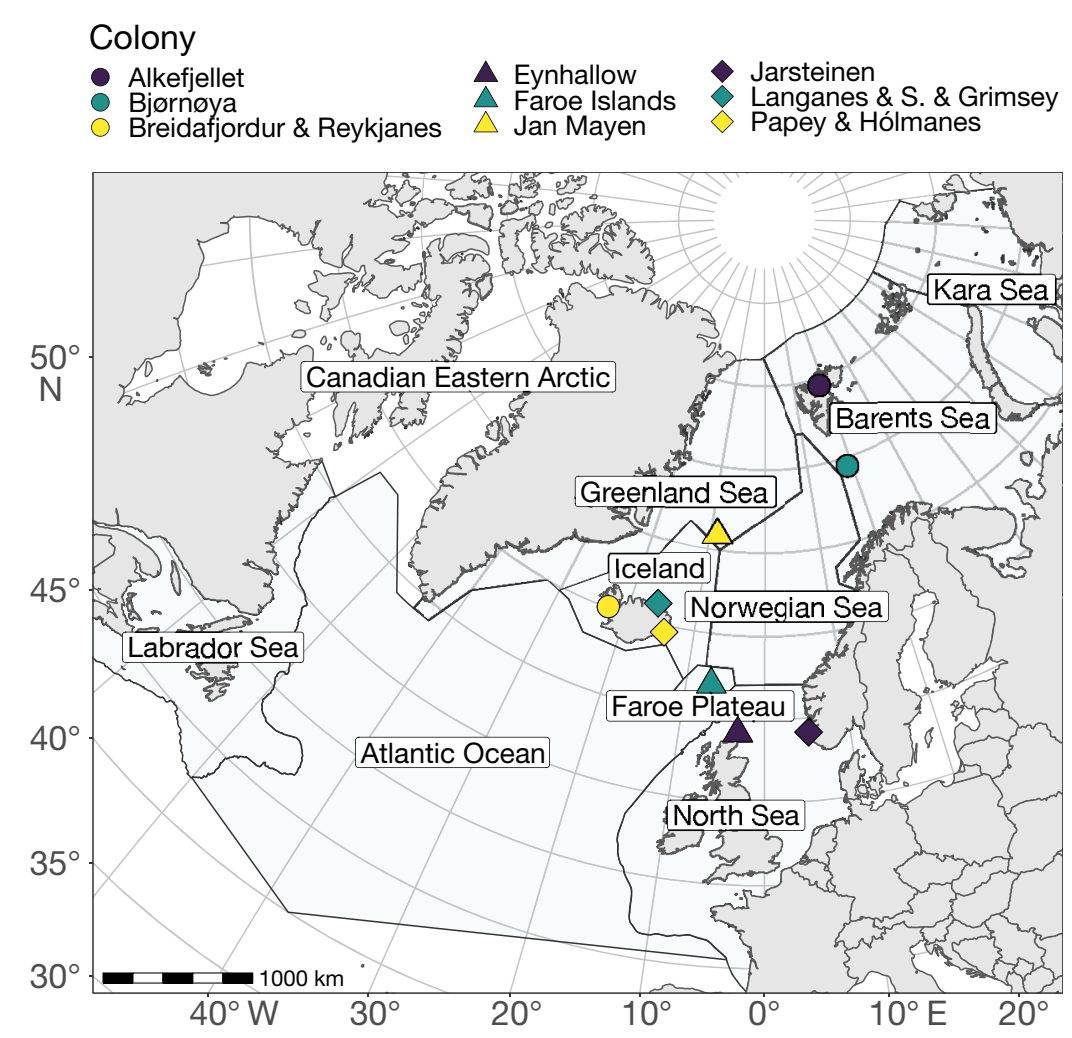

Fig. 1. Boundaries of the 10 northern fulmar wintering areas and locations of the studied colonies. S.: Skjálfandi 


\subsection{Processing of GLS data}

We used a dataset based on 569 GLS deployments (out of a total of 593) that provided light data for the full deployment duration. Herein, a 'track' refers to a time period of $1 \mathrm{yr}$, from one breeding season to the next. Some individuals were equipped with a geolocator for longer than $1 \mathrm{yr}$; therefore, 1 deployment could record several successive annual tracks. The number of tracks per individual was on average $2.3 \pm$ 0.1 SE (range 1-8 tracks ind. ${ }^{-1}$ ).

We focused on the non-breeding season (October to March) when birds are not central-place foragers and are therefore less constrained in their movements. Excluding the summer was also relevant to include highlatitude colonies that experience midnight sun, which prevented the detection of artificial light encounters.

Loggers sampled light every $3 \mathrm{~s}$, and recorded the maximum value in each 5 or 10 min interval. Different logger models recorded light differently. BAS and Biotrack loggers recorded light values from 0 (night) to a threshold value of 64 (day), whereas Migrate Technology loggers recorded light levels in lux. Loggers also sampled conductivity every 3, 6 or $30 \mathrm{~s}$, and recorded the number of wet samples in each 5 or $10 \mathrm{~min}$ bin between 0 (dry) and a maximum value of 200, 50 or 20 (wet). Conductivity data were standardized (from 0 to 1 ) to be comparable among the logger types.

Positions were estimated using a threshold method, where light data were used to first characterize local times for sunrise and sunset, and from these, estimate 2 positions per $24 \mathrm{~h}$ based on time of apparent midnight and noon for longitudes, and length of night and day for latitudes. Unrealistic positions were removed as described by Bråthen et al. (2021), using speed, angle and zone filters. In addition, the determination of latitudes (but not longitudes) is inaccurate during equinoxes when day length is similar everywhere on the globe. Therefore, positions estimated during the equinox periods (8 September to 20 October and 20 February to 3 April) were also removed (Frederiksen et al. 2012, Bråthen et al. 2021). Finally, many locations could not be estimated when the birds were situated within the polar night area. These successive filters led to a heavily biased dataset, owing to the non-random distributions of data gaps (both in time, during the equinoxes, and in space, in the areas affected by the polar night). To alleviate this bias, all filtered-out locations were reestimated using an algorithm that interpolates missing locations between 2 known locations. Briefly, this algorithm, building on a linear interpolation method originally proposed by Technitis et al. (2015), uses available additional information (e.g. light levels, land masks, longitudes during the equinoxes) to determine a plausible location for each timestamp at which a location is missing. The technical details can be found in Fauchald et al. (2019).

\subsection{Encounter detection}

To retain only periods of night in the raw light dataset, we used time of sunrise and sunset (hereafter twilight events), obtained when calculating positions. To avoid detecting potential remaining sunlight, we applied 2 corrections. Firstly, we removed light data 30 min around each twilight event. We then applied a correction during the polar night period, as some twilight can occur around the solar noon. Consequently, we removed all light data from the 60 min around the estimated time of solar noon during the polar night. Solar noon was estimated by using the solar noon times $10 \mathrm{~d}$ before and after each polar night period.

We used a light intensity threshold method to detect encounters of fulmars with artificial lights as described by Krüger et al. (2017). Since the light sensitivity of different loggers varied (Fig. S1 in the Supplement), we used 3 different thresholds. Biotrack mk3006 and mk 3005, and BAS mk15, mk19, mk3, mk4 and mk7 formed the 'Biotrack-high' group. For these, we used the same threshold of 10 as in Krüger et al. (2017), then we adjusted the threshold for other recording modes to have comparable data in terms of number and duration of encounters. Therefore, we used a threshold of 5 for the 'Biotrack-low' group (Biotrack mk4093 and 4083, and BAS mk13, mk14 and mk18) and 20 for Migrate Technology loggers.

To avoid overestimating the number of encounters, we assessed whether 2 light detections belonged to the same encounter by using the Bout-Ending Criterion method in the R package 'DiveMove' (Sibly et al. 1990, Luque \& Guinet 2007). This method was originally designed for diving vertebrates (Sato et al. 2001) to detect whether successive dives belong to the same dive bout (a succession of dives, preceded and followed by longer breaks). We adapted the method to calculate the amount of time under which 2 light peaks could be considered as belonging to the same encounter (Text S1 in the Supplement).

The encounter detection process is summarized in Fig. 2. The positions of encounters were mapped using an azimuthal equidistant projection centred on the centroid of all fulmar positions. Their density was mapped into a raster where each cell is $200 \mathrm{~km}$ wide. 
This resolution was chosen based on the accuracy of GLS data (Phillips et al. 2004). We focused on the spatial rather than temporal variation because preliminary analyses showed only little interannual variation in the location of wintering areas (Fig. S2).

\subsection{Fishery data}

We used open-access data available from the Global Fishing Watch website (https://globalfishingwatch .org/). These data provide the cumulative number of fishing hours per pixel and per day on a $0.01^{\circ}$ pixel grid between 2012 and 2016. Data were merged into a raster where each cell is $200 \mathrm{~km}$ wide to be compared to the raster containing the density of encounters. Areas with high fishing intensity did not vary from year to year (Fig. S3), as mentioned in other studies (Guiet et al. 2019). We therefore pooled all years together. We also pooled all fishing vessel types, because our dataset contains mainly trawlers and fixed gears (Fig. S4). Fishing effort was calculated as the sum of fishing hours per grid cell, and we included all fishing gear types available in the dataset.

\subsection{Spatial analyses and wintering area definition}

To reduce the bias generated by varying numbers of tracks among colonies, and by variation in night duration (due to season and latitude), we applied a weighting correction to each detection:

$$
W D=\frac{1}{P_{n} \times N_{W}} \times \frac{1}{\min \left(\frac{1}{P_{n} \times N_{W}}\right)}
$$

where $P_{n}$ is the proportion of night-time per $24 \mathrm{~h}$ on the date of the detection, $N_{\mathrm{w}}$ is the number of winter tracks recorded in the colony from which the bird originated, and WD is the weighted value of the detection.

We used the method described by Cuthbert et al. (2005) to calculate an overlap index quantifying the

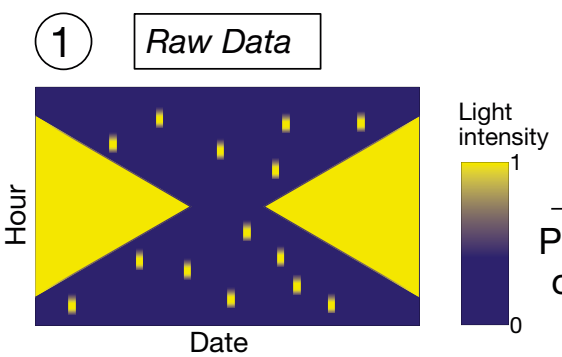

Date
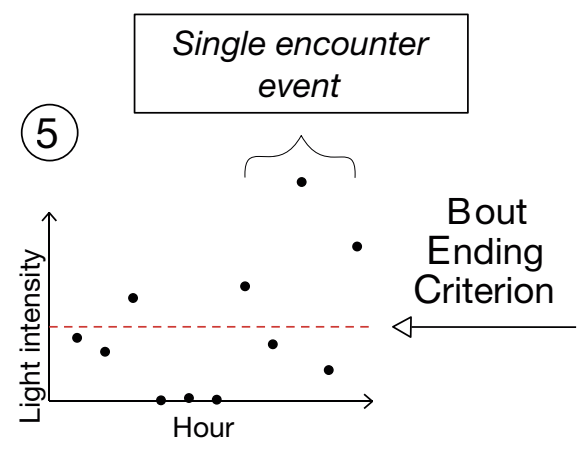

5

(2)

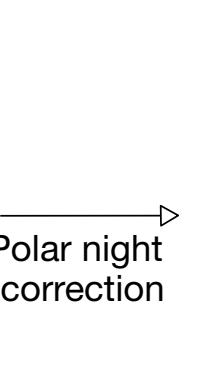

(2)

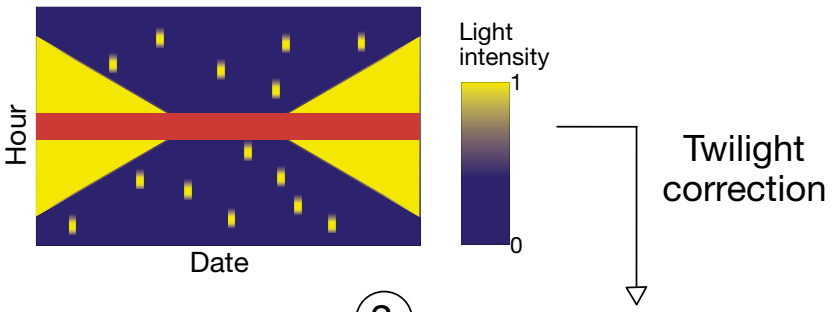

(3)

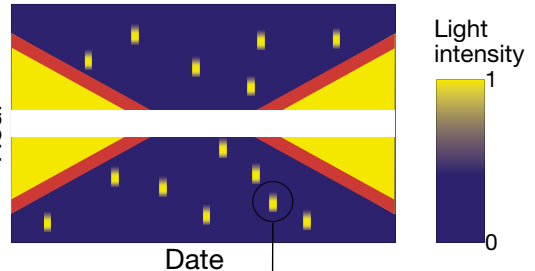

(4)
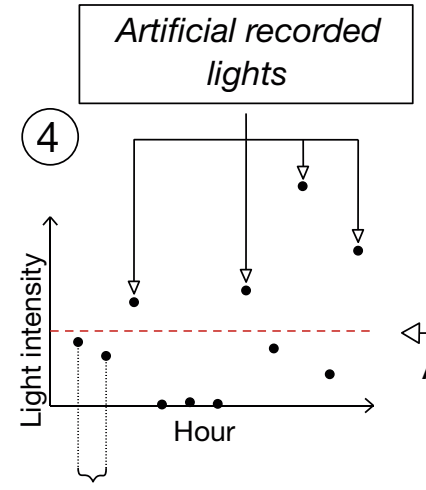

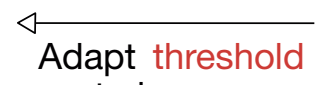

to logger

sensitivity

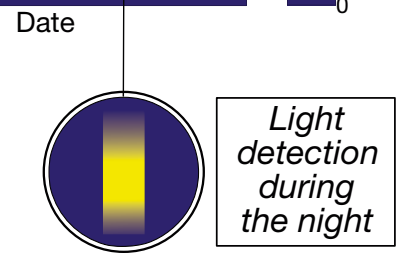

Fig. 2. Raw light data filtration and artificial light detection method: example for 1 individual encountering polar night. The first 3 panels represent the maximum light intensity per hour along date ( $x$-axis) and time ( $y$-axis). Yellow dots at night represent artificial lights. Panel 2 shows the filtration of twilight around noon during the polar night. Panel 3 shows the filtration of twilight before sunrise and after sunset events. Panels 4 and 5 represent the light intensity over time, showing an example of detections and encounter for 1 individual 
spatial overlap between fulmar light detections and fishing vessels. The index was obtained by multiplying 2 rasters, one representing the fishing effort (sum of fishing hours), and the second representing the density of light encounters calculated as the sum of WD values in each cell. The weighting correction of detection was used for mapping and overlap index only.

Using QGIS v3.12.2 (https://qgis.org), we defined wintering areas (Fig. 1) with different exposure levels to fishing activities. These areas were based on regions presented in the Large Marine Ecosystem report of the Protection of the Arctic Marine Environment (PAME, working group of the Arctic Council) (Skjoldal et al. 2013), to which we added 3 additional regions in the south to cover the entire study area.

\subsection{Assessing fulmar activity from conductivity data}

We used conductivity data to assess fulmar activity. Conductivity measures whether the geolocator (on the bird's leg) is in saltwater ('wet') or not ('dry'). During the non-breeding season, a bird that was not in contact with saltwater was assumed to be flying; if the leg was constantly immersed, the bird was assumed to be resting on the sea surface, and if it was alternating between short wet and dry periods, the bird was assumed to be foraging (Lecomte et al. 2010).

To analyse fulmar activity budgets, we aggregated the conductivity data by individual and by en. counter with artificial lights and calculated the proportion of time spent in each type of activity. We classified standardized conductivity values (see Section 2.2) in 3 activity types, as described by Lecomte et al. (2010): flying (conductivity <0.05), resting on the water $(>0.95)$ and actively foraging (intermediate values). For each individual, we randomly selected control periods of the same duration as the cumulative duration of all encounters for that individual and in the same wintering area but for which no encounter was detected.

\subsection{Statistical analyses}

We used R version 3.6.3 for all statistical analyses (R Core Team 2020). All R code used for the analyses is available at https://github.com/benjamindps/ Detections-of-seabird-fishery-interactions-usingGLS. A generalized linear mixed-effects model (GLMM) with a binomial distribution was used to test whether the probability of encountering artificial lights per night varied among wintering areas and colonies. A second GLMM with a binomial distribution was used to test for differences in encounter duration between colonies or wintering areas. More specifically, we tested the effect of the wintering areas and colonies on the probability of having short encounters ( $\leq 10 \mathrm{~min})$ versus long encounters (>10 $\mathrm{min})$, the median duration being $10 \mathrm{~min}$. Three wintering areas with very low numbers of detections had to be removed for this model to ensure convergence (between 4 and 12 detections for Kara Sea, Labrador Sea and Canadian Eastern Arctic, versus 90-1992 detections for the other wintering areas). All models were built using the 'lme4' package (Bates et al. 2015) in $\mathrm{R}$, including individual ID as a random effect to take the non-independence in the data into account.

We then investigated the changes in fulmar behaviour when encountering artificial lights using activity data. Each individual ( $\mathrm{n}=293$; 3 loggers failed to record conductivity) was characterized by activity data (proportion spent flying, foraging or resting) during encounters and during a randomly selected control period (i.e. when no light was detected; see Section 2.6 for details). No test was appropriate for comparing activity when encountering artificial lights and in control groups (e.g. distribution of the data was not symmetrical around the median as required for non-parametric Wilcoxon signed-rank tests, and/or the distribution of the differences between paired data was not normal as required for paired $t$-tests), and we therefore based our discussion on bootstrap confidence intervals (CIs). We calculated the 95\% CIs of the mean proportion of time spent in each activity (flying, foraging, resting) during encounters and in the control group using non-parametric bootstraps ('boot' and 'boot.ci' functions in the 'boot' package, Davison \& Hinkley 1997, Canty \& Ripley 2020). Non-overlapping CIs between the encounter and control groups were interpreted as significant differences. Results were exactly the same using Wilcoxon or $t$-tests, and we are therefore confident that our results and conclusions are robust.

Finally, to test whether the probability of encountering artificial light was consistent within individuals and within colonies, a repeatability test was performed using the 'rpt' function of the 'rptR' package (Stoffel et al. 2017). Repeatability was calculated as:

$$
R=\frac{V_{G}}{V_{G}+V_{R}}
$$


where $V_{G}$ is the among-individual (or amongcolony) variance component, and $V_{R}$ is the withinindividual (or within-colony) variance component when modelling the log-transformed (to fit normal distribution) number of encounters per 6 mo nonbreeding period with individual and colony as random effects.

\section{RESULTS}

Loggers detected artificial light at night at least once in the period October-March in 657 tracks by 296 individuals (note that activity data were only available for 293 individuals), out of a total of 751 tracks by 336 individuals (Table 1A). For these birds, the average number of encounters per track was $9.5 \pm 0.4$ (SE) (Fig. S5) with a mean duration of $35.6 \pm 0.7$ min (Fig. S6).

\subsection{Overlap between light encounters and fishing effort}

Four wintering areas (Barents Sea, North Sea, Norwegian Sea and Iceland) contained most of the light detections (86.1\% after weighting with Eq. 1), with the Barents Sea representing the highest proportion of detections (31.3\%, Table 1B, Fig. 3A,B). In contrast, there were very few detections in the Atlantic Ocean (6.3\%), Canadian Eastern Arctic $(0.1 \%)$ and Labrador Sea $(0.2 \%)$.

The fishing effort (defined as the sum of fishing hours per grid cell) was higher in Iceland, the Barents Sea, the North Sea (Fig. 3C). Applying the overlap index (Fig. 3D) confirmed that recorded light detections during the night spatially overlapped with the fishing effort. Again, this overlap was the strongest around Iceland, in the Barents Sea and the North Sea. Regarding the Norwegian Sea, we observed a low fishing effort combined with a moderate number of encounters, which led to a low overlap index.

\subsection{Bird activity during light detections}

We observed marked shifts in fulmar activity during light encounters (Fig. 4). Fulmars increased their time spent foraging by $37 \%$ and decreased their time spent resting and flying by 30 and $7 \%$, respectively (Fig. 4 ).

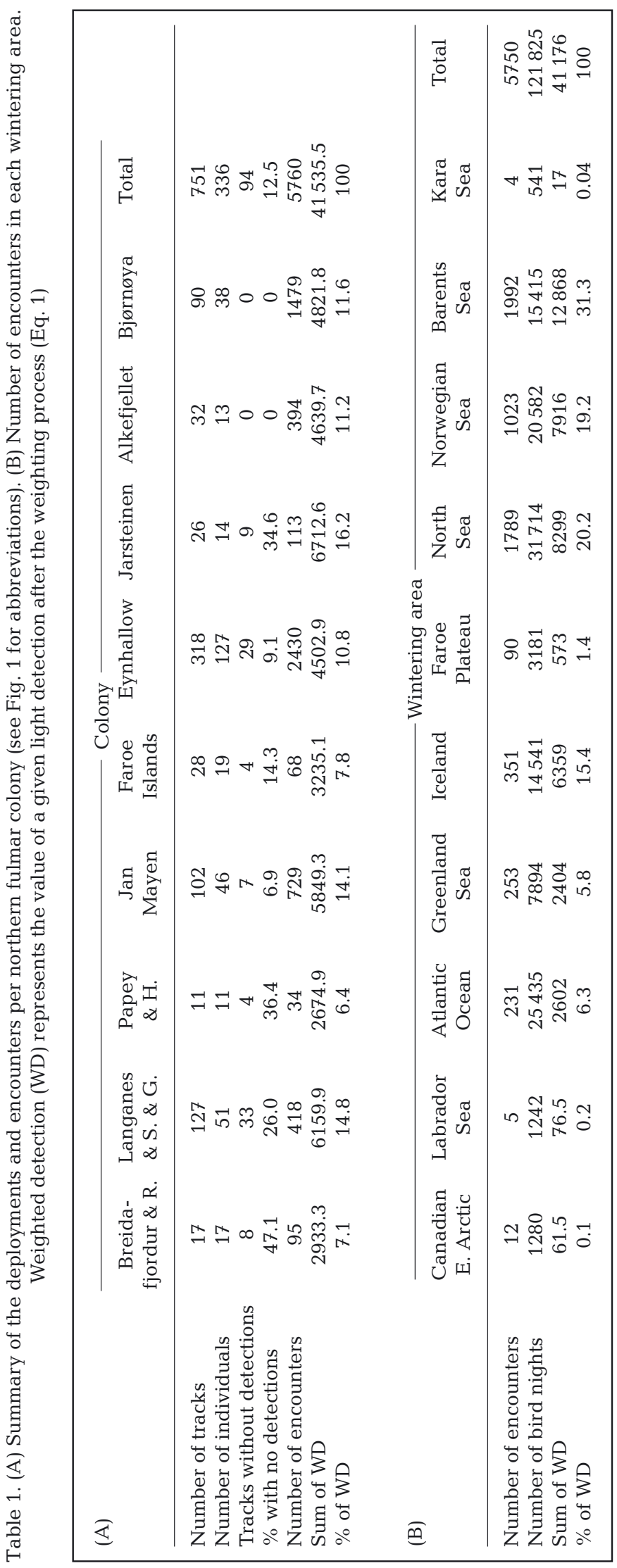


A.

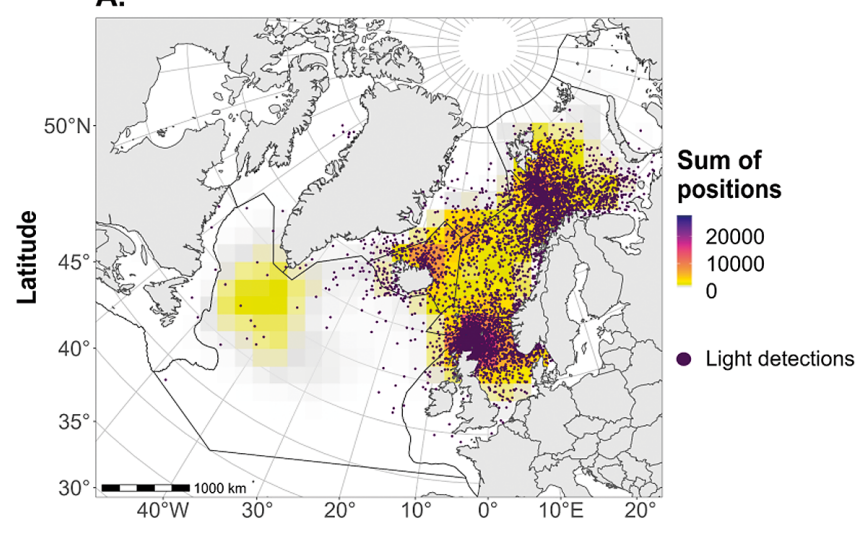

C.

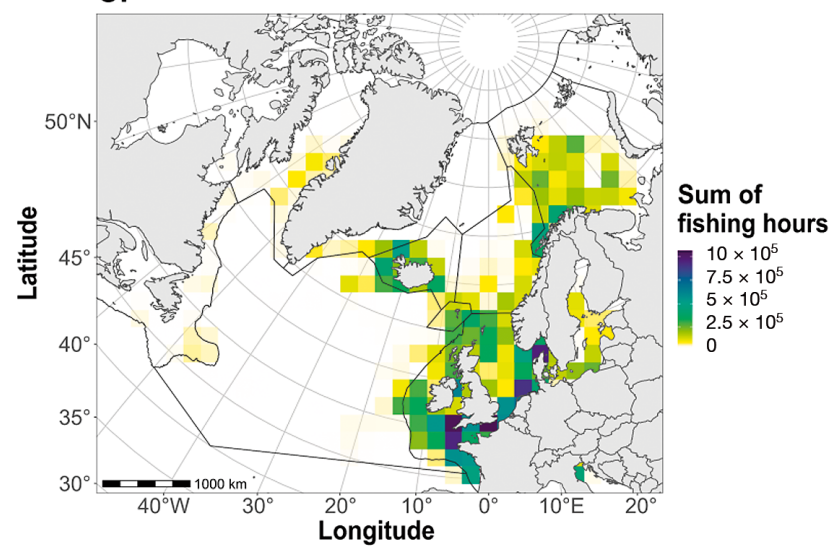

B.

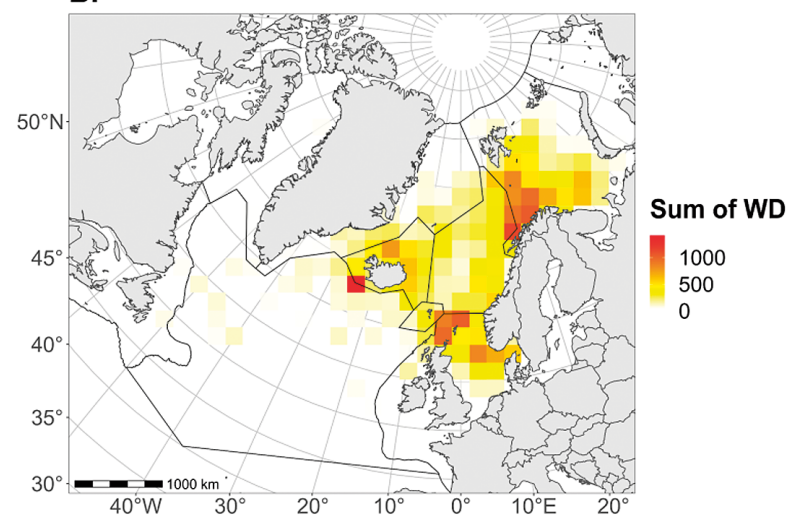

D.

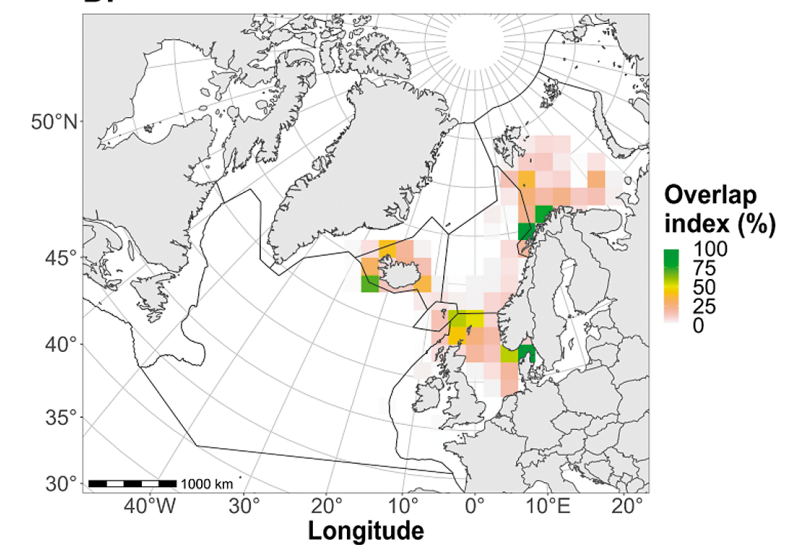

Fig. 3. Light detections at night overlap with fishing effort. (A) Positions of light detections. Each point represents 1 detection. The colour gradient represents the density of fulmar positions during the non-breeding season. (B) Raster of light detections after weighting (WD: weighted detection, i.e. the value of a given light detection after the weighting process). (C) Raster of the fishing effort (sum of the fishing hours per grid cell) recorded between 2012 and 2016. (D) Overlap between vessel density and light detections at night. Raster cells are $200 \mathrm{~km}$ wide. Azimuthal equidistant projection centred on the centroid of all fulmar positions

\subsection{Spatial variations}

Fulmars had, on average, a $0.04(4 \%)$ probability of encountering artificial lights per night (i.e. 4788 nights with at least 1 light encounter for a total of 121825 individual-nights). Independent of the total night duration, this probability varied among colonies and among wintering areas (Table 2A, Fig. 5). More specifically, birds from Bjørnøya (average probability of 0.09), Alkefjellet (0.06) and Eynhallow (0.04) had the highest probabilities of encountering light at night, while birds from the Faroe Islands (0.01), Langanes/ Skjálfandi/Grimsey (0.02) and Papey/Hólmanes (0.02) had the lowest probabilities (Fig. 5A). There were also differences in the probabilities of birds encountering artificial lights in the different wintering areas (Table 2A). The highest encounter probability was found in the Barents Sea (0.07; Fig. 5B) and the lowest in the Atlantic Ocean, Labrador Sea and Canadian Eastern Arctic (0.01; Fig. 5B). The proba- bility of having short ( $\leq 10 \mathrm{~min})$ or long (>10 min) encounters with artificial lights did not vary among colonies or wintering areas (Table 2B).

\subsection{Consistency of the probability of encountering artificial lights at night}

The frequency distribution of the number of encounters per non-breeding season (Fig. S5) shows that most tracks had a small number of detections, while some tracks had higher numbers (range: 0-68 encounters per 6 mo non-breeding season). The repeatability test revealed that $23.2 \pm 9.7 \%$ (mean \pm $\mathrm{SE}$ ) of the variation in the number of encounters per non-breeding season can be explained by the colony and $36.4 \pm 5.7 \%$ by the individual, independent of their colony (both likelihood ratio tests: $p<0.001$ ). These repeatability values suggest that birds from some colonies were more likely to encounter artificial 


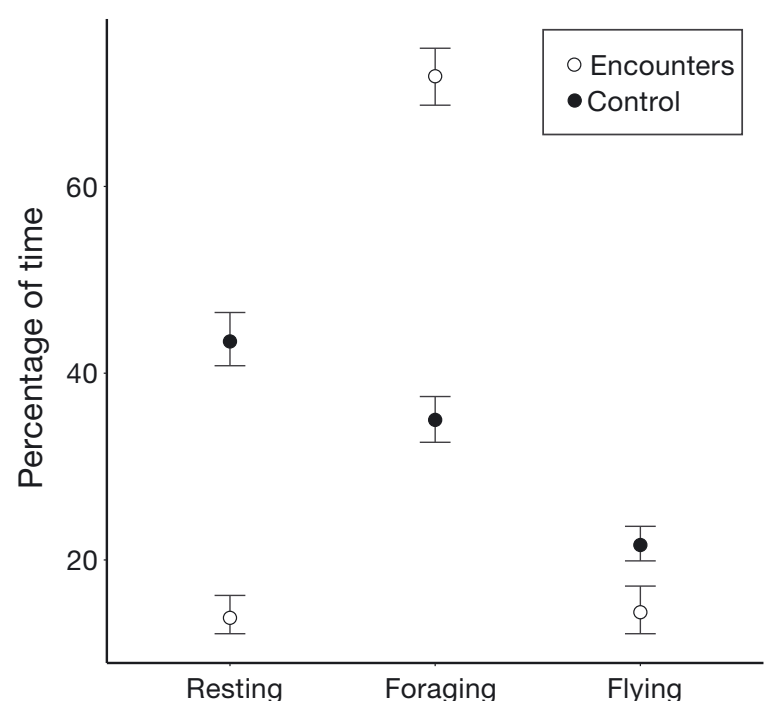

Fig. 4. Night activity budgets of 293 northern fulmars during encounters with artificial lights and in 'control' periods (i.e. with no light encounters). Activities are defined based on global location sensor (GLS) conductivity data and the proportion of time spent wet (flying if $<5 \%$, resting if $>95 \%$, active foraging otherwise; see Section 2 for details). Symbols represent the mean $\pm \mathrm{CI} \%$ of time spent in each activity lights at night, and that, independent of their colony, some birds were also more likely to encounter lights.

\section{DISCUSSION}

A previous study at a single South Atlantic colony (Krüger et al. 2017) highlighted the potential for using light data from GLS to detect nocturnal seabird-fishery interactions. Applying this same method to a multi-colony international study, we demonstrate how this low-cost technique can provide important insights into seabird-fisheries interactions across large-scale areas such as the North-East Atlantic. The clear overlap between light detections and fishing effort (Fig. 3D) matches the areas where fishing is the most intense in Europe (i.e. the North and Barents Seas and Iceland). This overlap, in addition to the increased foraging activity during encounters, strongly suggests that the detection of artificial light by bird-borne light-loggers can be used to investigate interactions between seabirds and fisheries in our system.

While detecting abnormal lights in the raw light data is a straightforward process, one limitation is that the nature of the light source is not known. In our study system, we were challenged by the presence of polar night at high latitudes. It could happen that no clear sunrise and sunset were detected, and that crepuscular light still appeared in the raw light data. This was fixed by filtering light data around the solar noon. For studies outside polar areas, any detection of daylight period (if some sunrise and sunset events are missed while processing the data) can be fixed by filtering detections that have the same duration as the daylight. Regarding artificial lights, we cannot exclude that we detected light sources other than fishing boats, either from other commercial vessels or offshore oil platforms, both of which also attract seabirds (Wiese et al. 2001, Ronconi et al. 2015). This could, for example, be the case in the Norwegian Sea, where we found a significant number of light detections despite a low level of fishing effort (Fig. 3). Likewise, some of the detections in the North Sea may come from

$\begin{array}{lcccc}\text { (B) Probability that light encounters at night last } \leq \text { or } & \mathbf{1 0} \mathbf{~ m i n} & \\ 1 \text { (intercept only) } & 2 & 7828.9 & 7832.9 & 0.0 \\ \text { Class } & 4 & 7826.6 & 7834.6 & 1.7 \\ \text { WArea } & 8 & 7820.2 & 7836.2 & 3.3 \\ \text { WArea + Class } & 10 & 7817.4 & 7837.4 & 4.5 \\ \text { Colony } & 10 & 7826.0 & 7846.0 & 13.1 \\ \text { Colony + Class } & 12 & 7822.9 & 7846.9 & 14.0 \\ \text { Colony + WArea + Class } & 18 & 7814.4 & 7850.4 & 17.5\end{array}$



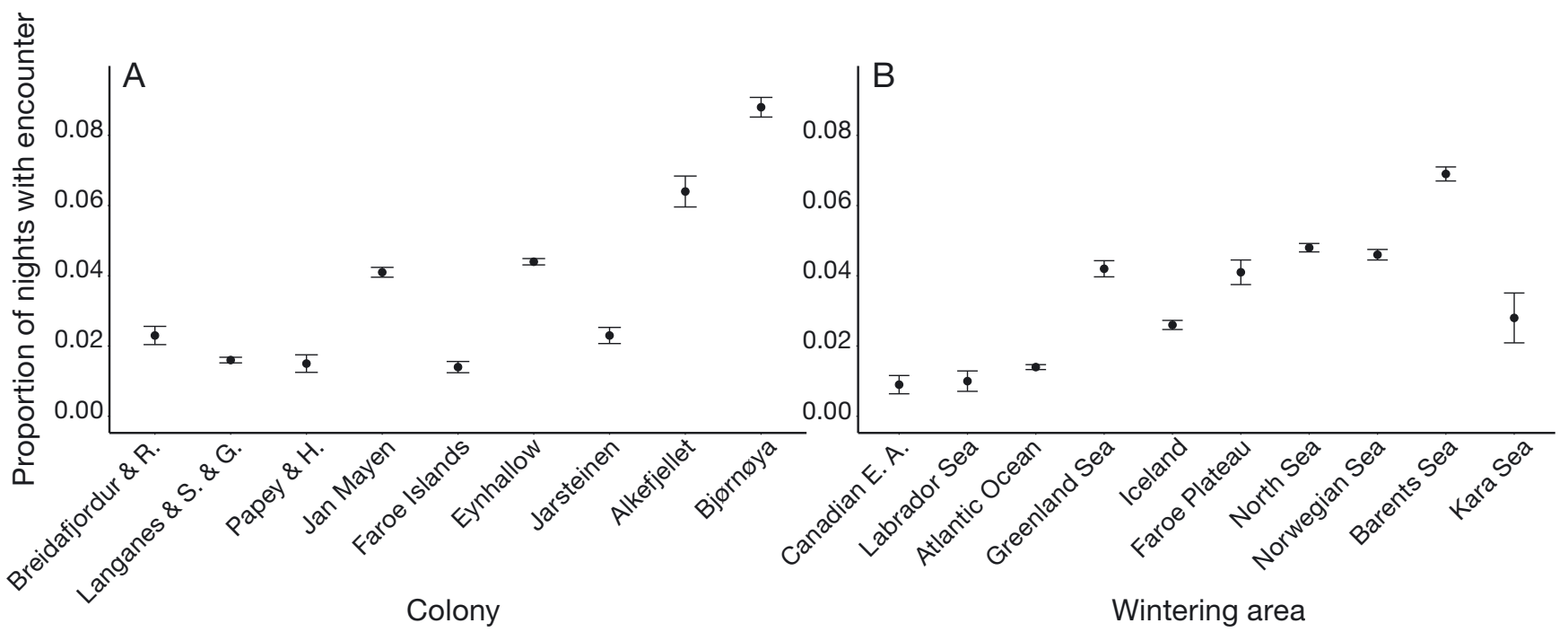

Fig. 5. Variation in the probability of encountering artificial light at night. Observed mean \pm SE probability (A) per northern fulmar colony and (B) per wintering area. See Fig. 1 for full colony and area names

ships other than fishing vessels, as ship traffic is heavier there than in other wintering areas (Jalkanen et al. 2016), yet the overlap between detections and fishing effort remained quite high, supporting the hypothesis that fulmars mostly encountered fishing vessels. In the English Channel and the Celtic Sea (i.e the southeast part of the North Sea wintering area in the present study), the overlap was very low despite a high vessel density (i.e. high fishing effort and ship traffic; Jalkanen et al. 2016), most likely due to few of the tracked birds using these areas (Fig. 3A). At sea, fulmars might also encounter lights from wind turbine fields, although we did not find any evidence in the literature that the lights of wind turbine fields attract seabirds. Finally, other artificial light sources might come from coastal areas. During the non-breeding season, fulmars are mostly on the open seas, but sometimes visit their colonies; however, none of their colonies were affected by light pollution, and the activity data did not reflect colony visits (= conductivity of 0 ). We are therefore confident that potential coastal light encounters are negligible and more generally that the artificial lights encountered are a good proxy of the encounters with fishing vessels, as supported by the activity data. To further validate our technique, it is interesting to note that lights can be used to detect fishing boats at a very different scale: satellites are now used to monitor fishing activities at nighttime by detecting the lights of fishing boats, in particular those that do not broadcast their positions (Waluda et al. 2002, Park et al. 2020, Li et al. 2021).

The description of the encounters highlighted the fact that in wintering areas with different levels of fishing effort, the duration of such events may not change (there was no effect on the probability that encounters last more or less than $10 \mathrm{~min}$ ), although their probability of occurring increased in wintering areas with higher fishing effort. Attraction of seabirds to fisheries in relatively small geographical areas has previously been demonstrated (Garcia-Barcelona et al. 2010), but to our knowledge, these interactions have not previously been assessed at as large a spatial scale as covered in the present study (i.e. the whole North-East Atlantic).

Not all of the colonies studied had the same exposure to fisheries. Colonies in which birds are the most likely to interact with fisheries were the ones located near fishing hotspots, respectively the North Sea for Eynhallow and the Barents Sea for Bjørnøya and Alkefjellet. There were also important inter-individual variations which accounted for more than $59 \%$ in the probability of encountering fishing vessels (combining repeatability at individual and colony levels, which is consistent with other studies (Patrick et al. 2015, Gianuca et al. 2017, Krüger et al. 2017). The tendency for some individual fulmars to be more closely associated with fishing boats than others has also been demonstrated through analysis of higherresolution GPS tracking and fisheries data in Scottish waters (Pirotta et al. 2018). This variation is likely to be partly related to sex and age class (Votier et al. 2013, Jimenez et al. 2016, Gianuca et al. 2017, Krüger et al. 2017). In terms of conservation, a sexbiased bycatch mortality can lead to changes in sex ratios and therefore a decline of the effective population size (Weimerskirch et al. 2005, Donald 2007). In a meta-analysis of global patterns of bycatch, 
Gianuca et al. (2017) found that mortality was skewed towards adults, further exacerbating deleterious effects on seabird populations. However, North Atlantic studies tend to be under-represented in Gianuca et al. (2017) and other bycatch studies (see Pott \& Wiedenfeld 2017). Studies that have been conducted in this region have highlighted that fulmars are commonly caught in a range of different fisheries (Anderson et al. 2011, Fangel et al. 2017, Bærum et al. 2019). Currently, the extent of these biases and the scale of threats are hard to estimate due to insufficient data on bycatch, although it is one of the greatest threats to seabirds (Croxall et al. 2012). Light-based assessments of interactions with vessels can now be integrated into individual-based demographic studies to further evaluate the basis and consequences of observed individual variation in interactions.

Even though we successfully identified a seabirdfishery overlap, it does not obviously mean that fulmars took advantage of fishing vessels to feed. Conductivity data helped us to highlight these interactions. Depending on the species and the studied area, some previous results indicated changes in behaviour during fishery encounters (Nel et al. 2002), while others did not (Grémillet et al. 2019). As we expected, fulmars showed behavioural changes during their interactions with fishing vessels. These modifications were specific to the encounter period and coincided, in every studied wintering area, with more time spent foraging around the boat and less time spent resting on the water. This is in line with onboard observations of fulmars (Hedd et al. 2016) and previous results on procellariforms (Nel et al. 2002).

Fulmars are attracted to fishing vessels (Skov \& Durinck 2000), with specific high concentrations of individuals around fisheries (Wahl \& Heinemann 1979). Pirotta et al. (2018) recently quantified the extent to which individual fulmars associated with vessels during the breeding season, when higherresolution GPS tracking data can be obtained. Our study is the first to provide colony-specific estimates of variation in the number of encounters between northern fulmars and fisheries during the non-breeding season at an individual scale (i.e. $9.5 \pm 0.4 \mathrm{SE}$ encounters per 6 mo of non-breeding season, varying from 0 to 68). Using the same method on another procellariform, Krüger et al. (2017) found that the number of nights with fishing vessel encounters was in the same order of magnitude (between 20 and 30 for the whole year) in the South Atlantic Ocean, where fishing effort is high and there is no discard ban pol- icy. Moreover, this raises questions concerning the prevalence of discards and offal in fulmar diet. In gannets, only $42 \%$ of the foraging behaviour around fishing vessels could be considered as direct foraging on fishery offal (Votier et al. 2013). In our study, although we could only detect the interactions occurring at night, their number remained relatively low. Thus, it seems likely that offal and discards represent a low proportion of fulmar diet during the non-breeding season according to our results. This is highly contrasting with diet studies conducted during the breeding season on birds captured both at the colony and at sea, where up to 72 and $40 \%$ of the diet, respectively, consisted of fishery discards (Lilliendahl \& Solmundsson 1997, Phillips et al. 1999). Additionally, fishery discards available to seabirds also fluctuate over longer time scales; in the North Sea, the number of seabirds that could be supported by fishery discards has declined by 39\% between 1990 (peak of fishery discards) and 2010 (Sherley et al. 2020). Further investigations would be needed to study the seasonal and interannual variations in the importance of discards in fulmar diet.

In the present study, we analysed only night data and indirect measurements of fulmar behaviour due to methodological constraints. We suggest that future studies should combine GLS light data with other sources of information like direct onboard observations of fulmar interactions with fisheries, which could provide information about bycatch mortality and any related biases that are crucial for conservation. Comparing day and night encounter probabilities could be useful to evaluate the role of artificial lights in attracting fulmars. Some seabird species that nest in burrows are actively attracted by artificial lights at night (Montevecchi 2006), but this is less common for birds nesting on the ground, including fulmars. In addition, knowing that procellariforms have well-developed olfaction and may use this sense rather than vision to search for food (Nevitt 2000), it is possible that they are more attracted by the fishing activity itself than by the light. Diet analyses would also help to assess potential differences in the reliance on fisheries among different wintering areas and between seasons. More recent methods to obtain dietary information, such as stable isotopes, DNA metabarcoding or fatty-acid analyses, could also be useful and have proven to be efficient in reconstructing the amount of discards eaten by seabirds (Mariano-Jelicich et al. 2017, McInnes et al. 2017, Conners et al. 2018). The nature of observed individual variation should also be explored further in relation to management policies that are typically only 
considered at larger population scales (Croxall et al. 2012, Gianuca et al. 2017). Finally, the activity shift observed during encounters that led to foraging around fisheries could have fitness consequences that remain to be investigated.

In conclusion, we found that fulmars encountered fisheries at night during the non-breeding season. The probability of encounter was highly variable between individuals but was higher in wintering areas with intense fishing effort. Fulmars tended to forage more and rest less during these periods. We provided a useful methodological framework to study seabirdfishery interactions at larger scale, which is crucial to understand and compare the consequences of management policies for entire seabird populations.

Acknowledgements. We thank all fieldwork funding sources and fieldwork teams who took part in the capture and recapture of GLS-equipped fulmars. Data were mostly collected as part of the SEATRACK project (www.seapop.no/en/ seatrack/). We thank Malin Kjellstadli Johansen, coordinator of the SEATRACK project, Benjamin Merkel and the SEATRACK project group, who provided critical feedback throughout the study. We thank Stephen Votier, Lucas Krüger and 2 anonymous reviewers for their very constructive comments.

\section{LITERATURE CITED}

Anderson ORJ, Small CJ, Croxall JP, Dunn EK, Sullivan BJ, Yates O, Black A (2011) Global seabird bycatch in longline fisheries. Endang Species Res 14:91-106

Bærum KM, Anker-Nilssen T, Christensen-Dalsgaard S, Fangel K, Williams T, Vølstad JH (2019) Spatial and temporal variations in seabird bycatch: incidental bycatch in the Norwegian coastal gillnet-fishery. PLOS ONE 14: e0212786

Barbraud C, Rolland V, Jenouvrier S, Nevoux M, Delord K, Weimerskirch H (2012) Effects of climate change and fisheries bycatch on Southern Ocean seabirds: a review. Mar Ecol Prog Ser 454:285-307

Barbraud C, Bertrand A, Bouchón M, Chaigneau A and others (2018) Density dependence, prey accessibility and prey depletion by fisheries drive Peruvian seabird population dynamics. Ecography 41:1092-1102

Bartumeus F, Giuggioli L, Louzao M, Bretagnolle V, Oro D, Levin SA (2010) Fishery discards impact on seabird movement patterns at regional scales. Curr Biol 20: 215-222

Bates D, Mächler M, Bolker B, Walker S (2015) Fitting linear mixed-effects models using lme4. J Stat Softw 67:1-48

Bearhop S, Thompson DR, Phillips RA, Waldron S and others (2001) Annual variation in great skua diets: the importance of commercial fisheries and predation on seabirds revealed by combining dietary analyses. Condor 103: 802-809

Bertrand S, Joo R, Smet CA, Tremblay Y, Barbraud C, Weimerskirch H (2012) Local depletion by a fishery can affect seabird foraging. J Appl Ecol 49:1168-1177
Bicknell AWJ, Oro D, Camphuysen K, Votier SC (2013) Potential consequences of discard reform for seabird communities. J Appl Ecol 50:649-658

Bodey TW, Jessopp MJ, Votier SC, Gerritsen HD and others (2014) Seabird movement reveals the ecological footprint of fishing vessels. Curr Biol 24:R514-R515

Bråthen VS, Moe B, Amélineau F, Ekker M and others (2021) An automated procedure (v2.0) to obtain positions from light-level geolocators in large-scale tracking of seabirds. A method description for the SEATRACK project. NINA Report 1893. Norwegian Institute for Nature Research, Trondheim. Available at https://brage.nina. no/nina-xmlui/handle/11250/2735757

Camphuysen K, Garthe S (1997) An evaluation of the distribution and scavenging habits of northern fulmars (Fulmarus glacialis) in the North Sea. ICES J Mar Sci 54: 654-683

Canty A, Ripley BD (2020) boot: bootstrap R (S-Plus) functions. $\mathrm{R}$ package version 1.3-25. https://cran.r-project.org/web/ packages/boot/boot.pdf

Cianchetti-Benedetti M, Dell'Omo G, Russo T, Catoni C, Quillfeldt P (2018) Interactions between commercial fishing vessels and a pelagic seabird in the southern Mediterranean Sea. BMC Ecol 18:54

* Clark BL, Vigfúsdóttir F, Jessopp MJ, Burgos JM, Bodey TW, Votier SC (2020) Gannets are not attracted to fishing vessels in Iceland - potential influence of a discard ban and food availability. ICES J Mar Sci 77:692-700

Conners MG, Goetsch C, Budge SM, Walker WA, Mitani Y, Costa DP, Shaffer SA (2018) Fisheries exploitation by albatross quantified with lipid analysis. Front Mar Sci 5: 113

Copello S, Quintana F (2009) Spatio-temporal overlap between the at-sea distribution of Southern giant petrels and fisheries at the Patagonian Shelf. Polar Biol 32: 1211-1220

Crawford RJM, Cruickshank RA, Shelton PA, Kruger I (1985) Partitioning of a goby resource amongst four avian predators and evidence for altered trophic flow in the pelagic community of an intense, perennial upwelling system. S Afr J Mar Sci 3:215-228

Croxall JP, Butchart SHM, Lascelles B, Stattersfield AJ, Sullivan B, Symes A, Taylor P (2012) Seabird conservation status, threats and priority actions: a global assessment. Bird Conserv Int 22:1-34

Cuthbert R, Hilton G, Ryan P, Tuck GN (2005) At-sea distribution of breeding Tristan albatrosses Diomedea dabbenena and potential interactions with pelagic longline fishing in the South Atlantic Ocean. Biol Conserv 121: 345-355

Davison AC, Hinkley DV (1997) Bootstrap methods and their applications. Cambridge University Press, Cambridge

* Diaz Pauli B, Sih A (2017) Behavioural responses to humaninduced change: why fishing should not be ignored. Evol Appl 10:231-240

Donald PF (2007) Adult sex ratios in wild bird populations. Ibis 149:671-692

Fangel K, Bærum KM, Christensen-Dalsgaard S, Aas Ø, Anker-Nilssen T (2017) Incidental bycatch of northern fulmars in the small-vessel demersal longline fishery for Greenland halibut in coastal Norway 2012-2014. ICES J Mar Sci 74:332-342

Fauchald P, Tarroux A, Bråthen VS, Descamps S and others (2019) Arctic-breeding seabirds' hotspots in space and time - a methodological framework for year-round mod- 
elling of environmental niche and abundance using light-logger data. NINA Report 1657. Norwegian Institute for Nature Research, Tromsø. Available at http://hdl. handle.net/11250/2595504

Frederiksen M, Moe B, Daunt F, Phillips RA and others (2012) Multicolony tracking reveals the winter distribution of a pelagic seabird on an ocean basin scale. Divers Distrib 18:530-542

Furness RW (2003) Impacts of fisheries on seabird communities. Sci Mar 67:33-45

Garcia-Barcelona S, Macias D, Ortiz de Urbina JM, Estrada A, Real R, Baez JC (2010) Modelling abundance and distribution of seabird by-catch in the Spanish Mediterranean longline fishery. Ardeola 57:65-78

Gianuca D, Phillips RA, Townley S, Votier SC (2017) Global patterns of sex- and age-specific variation in seabird bycatch. Biol Conserv 205:60-76

* Granadeiro JP, Brickle P, Catry P (2014) Do individual seabirds specialize in fisheries' waste? The case of blackbrowed albatrosses foraging over the Patagonian Shelf. Anim Conserv 17:19-26

* Grémillet D, Pichegru L, Kuntz G, Woakes AG, Wilkinson S, Crawford RJM, Ryan PG (2008) A junk-food hypothesis for gannets feeding on fishery waste. Proc R Soc B 275: 1149-1156

Grémillet D, Ponchon A, Paleczny M, Palomares MLD, Karpouzi V, Pauly D (2018) Persisting worldwide seabirdfishery competition despite seabird community decline. Curr Biol 28:4009-4013

* Grémillet D, Collet J, Weimerskirch H, Courbin N, Ryan PG, Pichegru L (2019) Radar detectors carried by Cape gannets reveal surprisingly few fishing vessel encounters. PLOS ONE 14:e0210328

Guiet J, Galbraith E, Kroodsma D, Worm B (2019) Seasonal variability in global industrial fishing effort. PLOS ONE 14:e0216819

*Gutowsky SE, Gutowsky LFG, Jonsen ID, Leonard ML, Naughton MB, Romano MD, Shaffer SA (2014) Daily activity budgets reveal a quasi-flightless stage during non-breeding in Hawaiian albatrosses. Mov Ecol 2:23

Hedd A, Regular PM, Wilhelm SI, Rail JF and others (2016) Characterization of seabird bycatch in eastern Canadian waters, 1998-2011, assessed from onboard fisheries observer data. Aquat Conserv 26:530-548

*Heubeck M, Mellor RM, Harvey PV, Mainwood AR, Riddington $R$ (1999) Estimating the population size and rate of decline of kittiwakes Rissa tridactyla breeding in Shetland, 1981-97. Bird Study 46:48-61

Humphries GRW, Huettmann F (2014) Putting models to a good use: a rapid assessment of Arctic seabird biodiversity indicates potential conflicts with shipping lanes and human activity. Divers Distrib 20:478-490

* Ivanova SV, Kessel ST, Espinoza M, McLean MF and others (2020) Shipping alters the movement and behavior of Arctic cod (Boreogadus saida), a keystone fish in Arctic marine ecosystems. Ecol Appl 30:e02050

Jalkanen JP, Johansson L, Kukkonen J (2016) A comprehensive inventory of ship traffic exhaust emissions in the European sea areas in 2011. Atmos Chem Phys 16:71-84

* Jimenez S, Domingo A, Brazeiro A, Defeo O and others (2016) Sex-related variation in the vulnerability of wandering albatrosses to pelagic longline fleets. Anim Conserv 19:281-295

Jurinovic L, Zec M, Mazal VD, Kralj J (2019) Explorative GPS-tracking of foraging movements by Audouin's gulls reveals no association with fishing vessels in Croatia. Ardea 107:213-221

Kelleher K (2005) Discards in the world's marine fisheries: an update. Food and Agriculture Organization of the United Nations, Rome

Krüger L, Paiva VH, Petry MV, Ramos JA (2017) Strange lights in the night: using abnormal peaks of light in geolocator data to infer interaction of seabirds with nocturnal fishing vessels. Polar Biol 40:221-226

Le Bot T, Lescroël A, Grémillet D (2018) A toolkit to study seabird-fishery interactions. ICES J Mar Sci 75:1513-1525

KLecomte VJ, Sorci G, Cornet S, Jaeger A and others (2010) Patterns of aging in the long-lived wandering albatross. Proc Natl Acad Sci USA 107:6370-6375

KLi J, Cai Y, Zhang P, Zhang Q and others (2021) Satellite observation of a newly developed light-fishing 'hotspot' in the open South China Sea. Remote Sens Environ 256: 112312

* Lilliendahl K, Solmundsson J (1997) An estimate of summer food consumption of six seabird species in Iceland. ICES J Mar Sci 54:624-630

* Luque S, Guinet C (2007) A maximum likelihood approach for identifying dive bouts improves accuracy, precision and objectivity. Behaviour 144:1315-1332

*Mallory ML, Hatch SA, Nettleship DN (2020) Northern fulmar (Fulmarus glacialis), version 1.0. In: Billerman SM (ed) Birds of the world. Cornell Lab of Ornithology, Ithaca, NY. https://doi.org/10.2173/bow.norful.01

Mariano-Jelicich R, Copello S, Seco Pon JP, Favero M (2017) Long-term changes in black-browed albatrosses diet as a result of fisheries expansion: an isotopic approach. Mar Biol 164:148

*Martínez-Abraín A, González-Solis J, Pedrocchi V, Genovart $M$ and others (2003) Kleptoparasitism, disturbance and predation of yellow-legged gulls on Audouin's gulls in three colonies of the western Mediterranean. Sci Mar 67:89-94

*McInnes JC, Jarman SN, Lea MA, Raymond B and others (2017) DNA metabarcoding as a marine conservation and management tool: a circumpolar examination of fishery discards in the diet of threatened albatrosses. Front Mar Sci 4:277

Montevecchi WA (2006) Influences of artificial light on marine birds. In: Rich C, Longcore T (eds) Ecological consequences of artificial night lighting. Island Press, Washington, DC, p 94-113

Nel DC, Ryan PG, Nel JL, Klages NTW, Wilson RP, Robertson G, Tuck GN (2002) Foraging interactions between wandering albatrosses Diomedea exulans breeding on Marion Island and long-line fisheries in the southern Indian Ocean. Ibis 144:E141-E154

Nevitt GA (2000) Olfactory foraging by Antarctic procellariiform seabirds: life at high Reynolds numbers. Biol Bull (Woods Hole) 198:245-253

* Oro D, Cam E, Pradel R, Martínez-Abraín A (2004) Influence of food availability on demography and local population dynamics in a long-lived seabird. Proc R Soc B 271: 387-396

* Park J, Lee J, Seto K, Hochberg T and others (2020) Illuminating dark fishing fleets in North Korea. Sci Adv 6: eabb1197

* Patrick SC, Bearhop S, Bodey TW, Grecian WJ, Hamer KC, Lee J, Votier SC (2015) Individual seabirds show consistent foraging strategies in response to predictable fisheries discards. J Avian Biol 46:431-440 
Phillips RA, Petersen MK, Lilliendahl K, Solmundsson J, Hamer KC, Camphuysen CJ, Zonfrillo B (1999) Diet of the northern fulmar Fulmarus glacialis: reliance on commercial fisheries? Mar Biol 135:159-170

Phillips RA, Silk JRD, Croxall JP, Afanasyev V, Briggs DR (2004) Accuracy of geolocation estimates for flying seabirds. Mar Ecol Prog Ser 266:265-272

Pirotta E, Edwards EW, New L, Thompson PM (2018) Central place foragers and moving stimuli: a hidden-state model to discriminate the processes affecting movement. J Anim Ecol 87:1116-1125

* Pott C, Wiedenfeld DA (2017) Information gaps limit our understanding of seabird bycatch in global fisheries. Biol Conserv 210:192-204

R Core Team (2020) R: a language and environment for statistical computing. R Foundation for Statistical Computing, Vienna

Regehr HM, Montevecchi WA (1997) Interactive effects of food shortage and predation on breeding failure of black-legged kittiwakes: indirect effects of fisheries activities and implications for indicator species. Mar Ecol Prog Ser 155:249-260

Rodríguez A, Rodríguez B (2009) Attraction of petrels to artificial lights in the Canary Islands: effects of the moon phase and age class. Ibis 151:299-310

Ronconi RA, Allard KA, Taylor PD (2015) Bird interactions with offshore oil and gas platforms: review of impacts and monitoring techniques. J Environ Manag 147:34-45

Sato K, Mori Y, Yoda K (2001) Defining dive bouts using a sequential differences analysis. Behaviour 138:1451-1466

Sherley RB, Ladd-Jones H, Garthe S, Stevenson O, Votier SC (2020) Scavenger communities and fisheries waste: North Sea discards support 3 million seabirds, 2 million fewer than in 1990. Fish Fish 21:132-145

Sibly RM, Nott HMR, Fletcher DJ (1990) Splitting behaviour into bouts. Anim Behav 39:63-69

Skjoldal HR, Mundy P, PAME-led Group of Experts on the Ecosystem Approach to Management (2013) Large Marine Ecosystems (LMEs) of the Arctic area. Revision of the Arctic LME map $15^{\text {th }}$ of May 2013, $2^{\text {nd }}$ edn. Arctic Council. https://pame.is/images/03_Projects/EA/LMEs/LME_ revised.pdf

Skov H, Durinck J (2000) Seabird distribution in relation to hydrography in the Skagerrak. Cont Shelf Res 20:169-187

Stoffel MA, Nakagawa S, Schielzeth H (2017) RptR: Repeatability estimation and variance decomposition by generalized linear mixed-effects models. Methods Ecol Evol 8:1639-1644

Sturludottir E (2018) Exploring the effects of discarding using the Atlantis ecosystem model for Icelandic waters. Sci Mar 82:51-62

Tasker M (2000) The impacts of fishing on marine birds. ICES J Mar Sci 57:531-547

Editorial responsibility: Stephen C. Votier (Guest Editor), Cornwall, UK

Reviewed by: L. Krüger and 2 anonymous referees
Technitis G, Othman W, Safi K, Weibel R (2015) From A to $\mathrm{B}$, randomly: a point-to-point random trajectory generator for animal movement. Int J Geogr Inf Sci 29: 912-934

Thompson PM (2006) Identifying drivers of change: Did fisheries play a role in the spread of North Atlantic fulmars? In: Camphuysen CJ, Boyd IL, Wanless S (eds) Top predators in marine ecosystems: their role in monitoring and management. Cambridge University Press, Cambridge, p 143-156

Troy JR, Holmes ND, Veech JA, Green MC (2013) Using observed seabird fallout records to infer patterns of attraction to artificial light. Endang Species Res 22:225-234

* Tyson C, Shamoun-Baranes J, Van Loon EE, Camphuysen KCJ, Hintzen NT (2015) Individual specialization on fishery discards by lesser black-backed gulls (Larus fuscus). ICES J Mar Sci 72:1882-1891

Votier SC, Heubeck M, Furness RW (2008) Using intercolony variation in demographic parameters to assess the impact of skua predation on seabird populations. Ibis 150:45-53

*Votier SC, Bicknell A, Cox SL, Scales KL, Patrick SC (2013) A bird's eye view of discard reforms: bird-borne cameras reveal seabird/fishery interactions. PLOS ONE 8:e57376

*Wagner EL, Boersma PD (2011) Effects of fisheries on seabird community ecology. Rev Fish Sci 19:157-167

*Wahl TR, Heinemann D (1979) Seabirds and fishing vessels: co-occurrence and attraction. Condor 81:390-396

Waluda CM, Trathan PN, Elvidge CD, Hobson VR, Rodhouse PG (2002) Throwing light on straddling stocks of Illex argentinus: assessing fishing intensity with satellite imagery. Can J Fish Aquat Sci 59:592-596

Watson RA (2017) A database of global marine commercial, small-scale, illegal and unreported fisheries catch 19502014. Sci Data 4:170039

*Weimerskirch H, Capdeville D, Duhamel G (2000) Factors affecting the number and mortality of seabirds attending trawlers and long-liners in the Kerguelen area. Polar Biol 23:236-249

*Weimerskirch H, Lallemand J, Martin J (2005) Population sex ratio variation in a monogamous long-lived bird, the wandering albatross. J Anim Ecol 74:285-291

Weimerskirch H, Collet J, Corbeau A, Pajot A and others (2020) Ocean sentinel albatrosses locate illegal vessels and provide the first estimate of the extent of nondeclared fishing. Proc Natl Acad Sci USA 117:3006-3014

*Wiese FK, Montevecchi WA, Davoren GK, Huettmann F, Diamond AW, Linke J (2001) Seabirds at risk around offshore oil platforms in the north-west Atlantic. Mar Pollut Bull 42:1285-1290

Y Yeh YM, Huang HW, Dietrich KS, Melvin E (2013) Estimates of seabird incidental catch by pelagic longline fisheries in the South Atlantic Ocean. Anim Conserv 16:141-152

Submitted: September 4, 2020

Accepted: February 17, 2021

Proofs received from author(s): May 6, 2021 